\title{
Serum C-reactive protein and neopterin concentrations in patients with viral or bacterial infection
}

\author{
A C Shaw
}

\begin{abstract}
Serum C-reactive protein and neopterin concentrations were measured in samples taken at an early stage in different types of infection to see whether the combination of markers could contribute to the diagnosis of infection and help distinguish between bacterial and viral infections, tuberculosis, and infections due to "other" pathogens. Both markers were significantly raised in all categories of infection compared with controls, and there were significant differences between the means of both markers when comparing several of the categories of infection. Only C-reactive protein concentrations in bacteraemic patients, however, were both sensitive and specific at distinguishing the type of infection. The additional use of neopterin estimation played only a minor part in increasing the specificity of diagnosis in tuberculosis and in viral infections.

On the basis of this study it was not considered worth the time and expense of performing neopterin assays in addition to $\mathrm{C}$-reactive protein estimations to differentiate viral from bacterial infection.
\end{abstract}

Serum C-reactive protein and neopterin concentrations have been used as non-specific indicators of infection, as well as of other conditions including various inflammatory and malignant disorders. C-reactive protein is produced by hepatocytes ${ }^{1}$ and is normally present as a trace constituent of the plasma, the median value in healthy adults being $0.8 \mathrm{mg} / \mathrm{l}$, with $90 \%$ having less than $3 \mathrm{mg} / \mathrm{l}$ and $99 \%$ less than $10 \mathrm{mg} / \mathrm{l}^{2}$ The rate of synthesis increases as part of the acute phase response within hours of acute injury, inflammation, or infection, ${ }^{3}$ reaching peak concentrations within 24-48 hours. ${ }^{4}$ C-reactive protein has been used to aid the diagnosis of infection and to distinguish bacterial from viral infections in various patient groups including children, ${ }^{5-7}$ those with leukaemia, ${ }^{8-10}$ and adults with bacteraemia. ${ }^{11-12}$ Bacterial infections tend to be associated with high Creactive protein concentrations, often more than $100 \mathrm{mg} / \mathrm{l}$, and viral infections with lower concentrations, frequently less than $10 \mathrm{mg} / \mathrm{l}$. Concentrations are usually less than 100 $\mathrm{mg} / \mathrm{l}$ in tuberculosis but vary with severity of disease. ${ }^{13}$
Neopterin (6-D-erythro-hydroxy propyl pteridine) is synthesised by macrophages stimulated by $\gamma$ interferon produced by $\mathbf{T}$ lymphocytes $^{14}$ and has thus been used as a measure of both macrophage function and cell medicated immunity. ${ }^{15}$ Its upper limit of normal in healthy adults is $9-10 \mathrm{nmol} / 1$. It is raised in viral infections, ${ }^{16}$ fatal septicaemias, ${ }^{17}$ and tuberculosis. ${ }^{18}$ The rate of rise is slower than that of C-reactive protein, peaking at 912 days after contraction of viral infection or after vaccination with live virus. ${ }^{19}$

It was expected from these studies that the concentrations and ratios of the two markers would differ noticeably in bacterial, viral, and other infections, and that the combination could be more discriminatory than the use of C-reactive protein estimation alone. Such an indication of the type of infecting agent could be of value to clinicians by giving an additional guide to the early management of the patients, such as whether antibiotics need to be given.

\section{Methods}

Serum C-reactive protein and neopterin concentrations were measured in 88 patients with infections caused by a variety of different organisms, and in healthy age and sex matched controls. For comparison with concentrations in non-infective inflammatory conditions a random group of 14 patients with rheumatoid factor positive arthritis were also tested (table 1).

Table 1 Numbers of patients

\begin{tabular}{|c|c|}
\hline $\begin{array}{l}\text { Acute bacteraemias } \\
\text { Pneumococci } \\
\text { S aureus } \\
\text { Streptococci } \\
\text { Escherichia coli } \\
\text { Klebsiella } \text { sp } \\
\text { Pseudomonas sp } \\
\text { Salmonella sp } \\
\text { Meningococcus }\end{array}$ & $(\mathbf{n}=30)$ \\
\hline Tuberculosis & $(n=13)$ \\
\hline $\begin{array}{l}\text { Viral infections } \\
\text { Hepatitis A } \\
\text { Cytomegalovirus } \\
\text { Epstein-Barr virus } \\
\text { Rubella } \\
\text { Parvovirus B19 }\end{array}$ & $(\mathrm{n}=32)$ \\
\hline $\begin{array}{l}\text { “Other" infections } \\
\text { Chlamydia psittaci } \\
\text { Mycoplasma pneumoniae } \\
\text { Coxiella burnetti } \\
\text { Toxoplasma gondii }\end{array}$ & $(n=13)$ \\
\hline $\begin{array}{l}\text { Total numbers of infections } \\
\text { Controls } \\
\text { Rheumatoid arthritis }\end{array}$ & $\begin{array}{l}88 \\
88 \\
14\end{array}$ \\
\hline
\end{tabular}

Correspondence to: Dr A C Shaw

Accepted for publication 7 February 1991
Department of Microbiology, Joyce Green Hospital, Dartford, Kent DA1 
The infected patients were an unselected cohort all of whose samples had been processed by the microbiology laboratory. Only one of these (a leukaemic patient with bacteraemia) was known to be immunosuppressed. All the bacteraemic patients and $61 \cdot 5 \%$ of the tuberculous patients were inpatients. All the patients with viral or other infections had been seen as outpatients or by general practitioners.

The 88 age and sex matched controls comprised 59 blood donors attending the North London Blood Transfusion Clinic, nine members of staff at the Central Middlesex Hospital from whom blood samples had been taken to test for rubella immunity, and 20 elderly patients from whom blood samples had been taken for syphilis screening (all negative) because of symptoms of deafness or dementia, but who were otherwise healthy. None of the controls had evidence of infection, malignancy, or inflammatory disease.

Most serum samples from bacteraemic and tuberculous patients had been sent to the microbiology laboratory for other tests, such as viral antibodies or gentamicin assays. The samples used were taken on the same day, or as soon as possible, as the specimen from which the diagnosis had been made (blood culture or sputum). The average time that samples were taken from bacteraemic patients was 2.4 days after the positive blood culture. For tuberculous patients the average number of days after the positive specimen was 0 . For viral and "other" conditions serum samples from which the diagnosis had been made were used. Where both acute and convalescent samples had been sent, the acute sample was used.

Sera were stored at $-40^{\circ} \mathrm{C}$ after being divided into two separate tubes for the two assays.

C-reactive protein was measured by rate nephelometry using a Beckman Auto ICS machine. ${ }^{20}$ Neopterin was measured by radioimmunoassay using IMMUtest Neopterin (Henning, Berlin). ${ }^{21}$ The coefficient of variation for C-reactive protein assay was $2.75 \%$ intrabatch, $3.69 \%$ inter-batch. For the neopterin assay the coefficient of variation was $12.5 \%$ and $8.6 \%$, respectively.

\section{Results}

The C-reactive protein and neopterin concentrations in the different patient categories are shown in figs 1 and 2 .

The means of both markers in all categories of infections were higher than the mean controls for each category. These differences were significant by matched Student's $t$ tests, performed on the natural logarithms of the values $(\mathrm{p}<0.01)$.

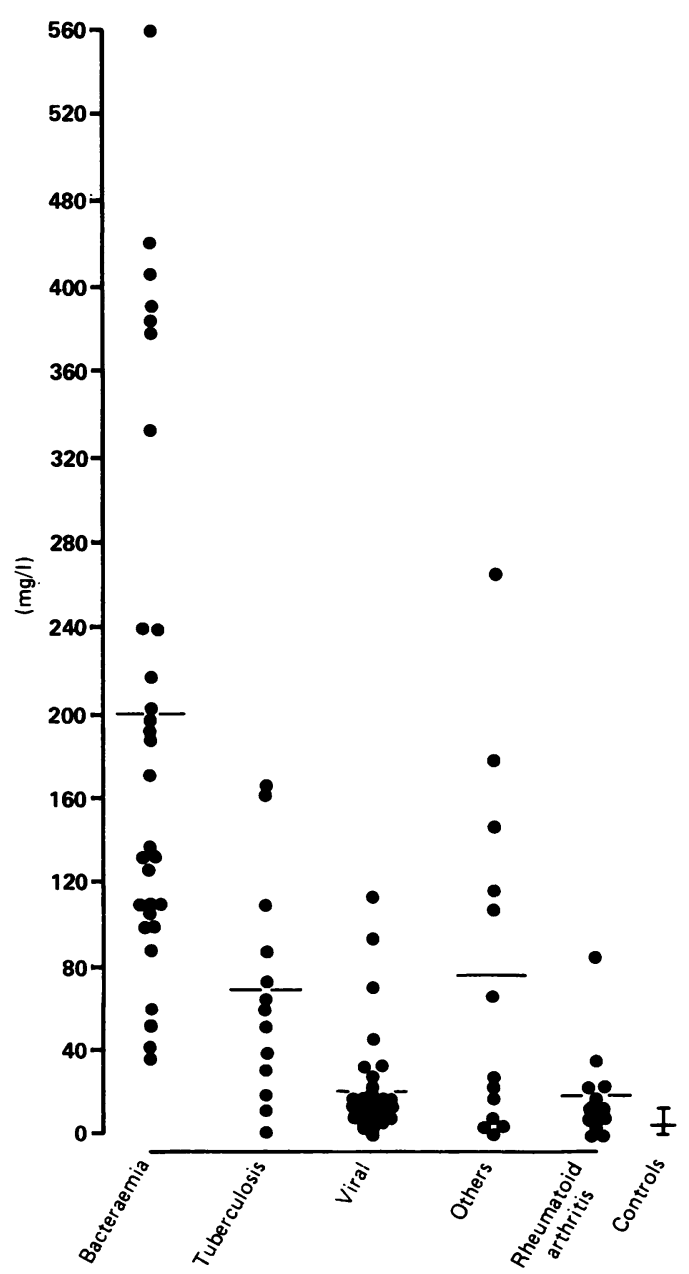

Figure $I$ C-reactive protein concentrations.

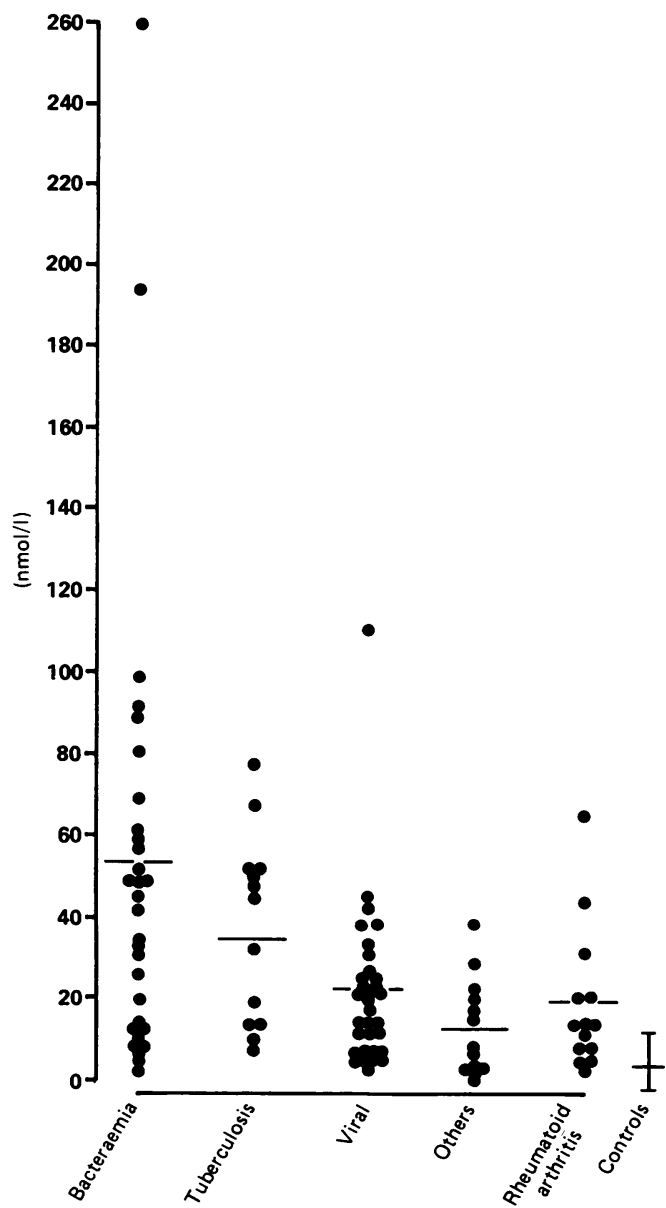

Figure 2 Neopterin concentrations. 
Table 2 Mean $C$-reactive protein and neopterin concentrations compared between different categories of patients by unmatched $t$ tests

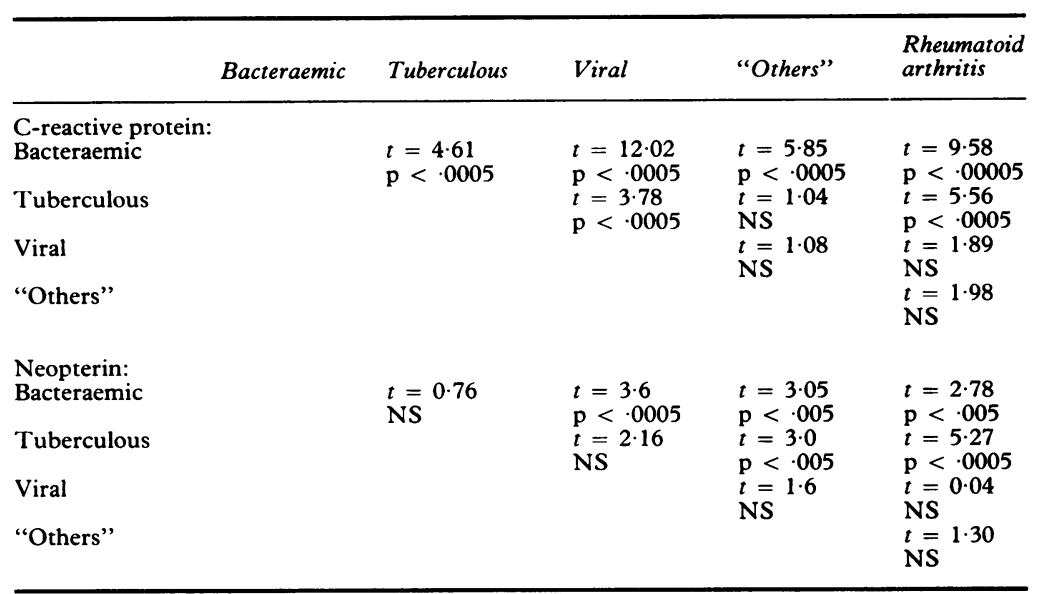

NS $=$ Not significant at $p=0.01$
A C-reactive protein of $40-100 \mathrm{mg} / 1$ was $46 \%$ sensitive and $88.8 \%$ specific for tuberculosis, with a predictive value of $40 \%$, and a C-reactive protein of $10-40 \mathrm{mg} / 1$ was $68.7 \%$ sensitive and $84.3 \%$ specific for viral infections, predictive value $66.6 \%(81.5 \%$ if rheumatoid positive patients were excluded).

The neopterin concentrations did not contribute to the diagnosis of bacteraemia, but a combination of ranges of C-reactive protein and neopterin values could improve the specificity of diagnosis in tuberculous and viral infections. Thus a C-reactive protein of less than $100 \mathrm{mg} / \mathrm{l}$ with a neopterin concentration of more than $40 \mathrm{nmol} / 1$ was $95.7 \%$ specific for tuberculosis, although only $31 \%$ sensitive. The predictive value was $50 \%(66.6 \%$ if rheumatoid factor positive patients were excluded). A C-reactive protein of $10-40 \mathrm{mg} / \mathrm{l}$ with a neopterin concentration of 10-40 nmol/1 was $92.5 \%$ specific for viral infections $(100 \%$ if rheumatoid factor positive patients were excluded), but the sensitivity was only $43.8 \%$. The predictive value was $73 \cdot 7 \% \quad(100 \%$ if rheumatoid factor positive patients were excluded). The concentrations in "other" infections were too diverse to have any typical combinations of concentrations. reactive protein of bacteraemic patients and al the other categories, and between the mean Creactive protein of the tuberculous and viral categories (table 2). Differences in mean neopterin concentrations were significant $(\mathrm{p}<0.005)$ between bacteraemias and all other categories except tuberculous and between tuberculous and "others".

There was no significant difference at $p=0.01$ between either the mean logged Creactive protein or neopterin concentrations in Gram negative compared with Gram positive bacteraemias.

The coefficient of correlation of all logged Creactive protein and neopterin concentrations of infected patients was significant $(r=0.536)$, suggesting that the $\mathrm{C}$-reactive protein and neopterin values do not give completely independent information.

The ratios of C-reactive protein $(\mathrm{mg} / \mathrm{l})$ to neopterin ( $\mathrm{nmol} / \mathrm{l})$ calculated from the logged data tended to be higher in bacteraemic than viral infections, a ratio of less than 1 being a contraindication for bacteraemia (table 3 ).

Using the values in the 88 infected patients and the 14 rheumatoid factor positive patients, a value of more than $100 \mathrm{mg} / \mathrm{l}$ C-reactive protein was associated with bacteraemia with a clinical sensitivity of $80 \%$ and a specificity of $87.5 \%$. The predictive value of a C-reactive protein of more than $100 \mathrm{mg} / \mathrm{l}$ for bacteraemia was $73 \cdot 5 \%$.

Table 3 Ratios of natural logarithmic values of $C$ reactive protein $(\mathrm{mg} / \mathrm{l})$ and neopterin $(\mathrm{nmol} / \mathrm{l})$ in different categories of patients

\begin{tabular}{llll}
\hline & $\begin{array}{l}\text { Mean } \\
\text { ratio }\end{array}$ & $S D$ & $\begin{array}{l}\text { No with ratio of } \\
\text { less than 1 }\end{array}$ \\
\hline Bacteraemias & $5 \cdot 23$ & $4 \cdot 72$ & $0 \%$ \\
Tuberculosis & $2 \cdot 19$ & 1.32 & $15 \cdot 4 \%$ \\
Viral & $2 \cdot 19$ & 3.3 & $48.5 \%$ \\
"Others" & 5.9 & 5.8 & $23.1 \%$ \\
Rheumatoid & 1.38 & 1.57 & $64 \%$ \\
\hline
\end{tabular}

\section{Discussion}

On the basis of previous studies it was anticipated that neopterin concentrations would be raised significantly more in patients with viral infections than in bacteraemic patients, as opposed to the tendency for Creactive protein to be higher in bacteraemia. This did not prove to be the case, however, although there was a tendency for the ratio of C-reactive protein to neopterin concentrations to be higher in bacterial than in viral infections. This finding agrees with Myara's study, ${ }^{22}$ which compared C-reactive protein and neopterin concentrations in postoperative infections in heart transplant recipients. The authors found that when serum C-reactive protein and/or neopterin concentrations were high, a ratio of C-reactive protein:neopterin of more than 1 was observed in all bacterial infections and a ratio of less than 1 during viral infections and rejection episodes. They did find that the neopterin concentration was much higher, however, in viral infections than in bacterial infections, unlike this present study. Their values were presumably peak concentrations, which could only be found by testing daily samples. This would be impractical except in specialist units, and waiting for the peak concentration to be reached before calculating the ratio could impose an unnecessary delay on diagnosis.

In our study samples taken soon after the onset of bacteraemia could readily be obtained, but less frequently so after viral or "other" infections, which tended to be investigated at a later stage in the illness. Although samples were taken soon after diagnosis in tuberculous patients, the patients may have been infected for some time before a diagnostic specimen was taken. These are the times, however, at which patients present with, or are investigated for, 
these illnesses, therefore it is practical to compare single samples which could be taken to aid diagnosis at this time.

Although C-reactive protein concentrations peak early in infection, neopterin concentrations peak later, so should still have been raised in most samples in the viral and "other" categories at the time they were taken, assuming the illness affects neopterin concentrations.

The wide range of concentrations measured in each category could not be explained by the timing of samples alone. There seemed to be little correlation between either the C-reactive protein or neopterin concentrations and the severity of bacteraemia, although unlike Strohmaier's study, ${ }^{17}$ all the patients survived. Both markers, however, were related to the severity of illness in tuberculosis and rheumatoid arthritis, in accordance with findings from other studies. ${ }^{131823}$ The wide spread of concentrations found in viral infections and in the group affected by "other" pathogens might be expected to be partly related to the variety of different pathogens and resulting disease processes. In viral infections the differences between groups of organisms were not noticeable. For example, the mean C-reactive protein and neopterin concentrations for rubella and parvovirus infections together were $21.4 \mathrm{mg} / \mathrm{l}$ and $13.5 \mathrm{nmol} / 1$, respectively; for Epstein-Barr virus and cytomegalovirus infections the means were $39.7 \mathrm{mg} / 1$ and $20.6 \mathrm{nmol} / \mathrm{l}$. In the "other" category the resulting disease processes could have influenced the concentrations. For example, the mean C-reactive protein in the two toxoplasma infections was only $4.5 \mathrm{mg} / 1$ compared with a mean of $69.9 \mathrm{mg} / \mathrm{l}$ for the mycoplasma, psittacosis, and coxiella infections combined, these three organisms causing pneumonia.

All categories of infected patients had significantly raised C-reactive protein and neopterin concentrations compared with the age and sex matched controls, so they could both be used to ascertain whether an infective or inflammatory process is going on. It may not be possible, however, to distinguish, for example, a viral infection and rheumatoid arthritis using these markers.

Only C-reactive protein concentrations were both sensitive and specific at distinguishing bacteraemias from the other categories of infection. Mean neopterin concentrations alone showed a significant difference between bacterial and viral infections, but in the opposite way to that expected from other studies. The addition of neopterin to C-reactive protein concentrations contributed little to the diagnosis of bacteraemia, their only role being to increase the specificity and predictive value in the diagnosis of viral infections and tuberculosis, but at the expense of sensitivity.
In conclusion, it was not considered worth the expense and inconvenience of performing estimations of neopterin concentrations in addition to those of $\mathrm{C}$-reactive protein to aid the diagnosis of infection, especially using radioimmunoassay kits with a short shelf-life, which would make routine testing impractical.

1 Hurlimann J, Thorbecke GJ, Hochwald GM. The liver as the site of C-reactive protein formation. J Exp Med 1966;123:365-78.

2 Pepys MB. C-reactive protein 50 years on. Lancet 1981; i:653-7.

3 Kuchner I, Feldman G. Control of the acute phase response. Demonstration of C-reactive protein synthesis and secretion by hepatocytes during acute inflammation in the rabbit. J Exp Med 1978;148:466-77.

4 Peltola H, Holmberg C. Rapidity of C-reactive protein concentration in detecting potential septicemia. Pediatr Infect Dis 1983;2:374-6.

5 McCord FB, Jenkins JG, Lim JHK. C-reactive protein concentration as screening test for bacterial infection in concentration as screening test for bacterial
febrile children. $B r M e d ~ J 1985 ; 291: 1685-6$.

6 Peltola H, Saarinen UM, Siimes MA. C-reactive protein in rapid diagnosis and follow up of bacterial septicemia in children with leukaemia. Pediatr Infect Dis 1983;2:370-3.

7 McCarthy PL, Frank AL, Ablow RC, Master SJ, Dolan TF Jr. C-reactive protein test in the differentiation of bacterial and viral pneumonia. J Pediatrics 1978;92:454-6.

8 Mackie PH, Crockson RA, Stuart J. C-reactive protein for rapid diagnosis of infection in leukaemia. J Clin Pathol 1979;32:1253-6.

9 Rose PE, Johnson SA, Meakin M, Mackie PH, Stuart J. Serial study of C-reactive protein during infection in leukaemia. J Clin Pathol 1981;34:263-6.

10 Schofield KP, Voulgari F, Gozzard DI, Leyland MJ Beeching NJ, Stuart J. C-reactive protein concentration as a guide to antibiotic therapy in acute leukaemia. J Clin Pathol 1982;35:866-9.

11 McCabe RE, Remington JS. C-reactive protein in patients with bacteraemia. J Clin Microbiol 1984;20:317-9.

12 Lindback S, Hellgren U, Julander I, Hanson L. The value of $C$-reactive protein as a marker of bacterial infection in patients with septicaemia/endocarditis and influenza. Scand J Infect Dis 1989;21:543-9.

13 Maasilta P, Kostiala AAI. Serum levels of C-reactive protein in patients with pulmonary tuberculosis and malignant tumours of the chest. Infection 1989;17:13-4

14 Huber C, Lang A, Niederweiser D, et al. Immune response associated production of neopterin: release from macrophages primarily under control of immune interferon. Biochemical and Clinical Aspects of Pteridines. 1984;3 245-50.

15 Fuchs D, Hausen A, Reibnegger G, Werner ER, Dierich $M P$, Wachter $H$. Neopterin as a marker for activated cellmediated immunity: application in HIV infection. Immunology Today 1988;9:150-5.

16 Wachter H, Hausen A, Grassmayr K. Increased urinary excretion of neopterin in patients with malignant tumours excretion of neopterin in patients with malignant tumours
and with virus diseases. Hoppe-Seylers' Z. Physiol Chem and with virus dise

17 Strohmaier W, Redi H, Schlag G, Inthorn D. D-erythroneopterin plasma levels in intensive care patients with and without septic complications. Crit Care Med 1987;15 757-60.

18 Fuchs D, Hausen A, Kosanowski H, Reibnegger G, Wachter $H$. Neopterin as an index of immune response in patients with tuberculosis. Lung 1984;162:337-46.

19 Reibnegger G, Fuchs D, Grubauer G, Hausen A, Wachter $H$. Neopterin excretion during incubation period, clinical manifestation and reconvalescence of viral infection. $B$ io manifestation and reconvalescence of viral infection. Bio-

chemical and Clinical Aspects of Pteridines 1984;3:433-47.
Gill CW tion of C-reactive protein assay using a rate immunonetion of C-reactive protein assay using a rate immunone-
phelometric procedure. Am J Clin Pathol 1981;75:50-5.

phelometric procedure. Am J Clin Pathol 1981;75:50-5.
21 Rokos H, Rokos K, Kern P, Dietrich M. Radioimmunoassay for neopterin serum levels in patients with viral infection, lymphadenopathy syndrome, AIDS, leprosy and in normals after hepatitis vaccination. Biochemical and Clinical Aspects of Pteridines 1984;3:503-13.

22 Myara I, Atger V, Cosson C, et al. Simultaneous determination of serum neopterin and $\mathrm{C}$-reactive protein as markers of infection in heart-transplant recipients. Clin Chem 1989;35:1258-9.

23 McConkey B, Crockson RA, Crockson AP. The assessmen of rheumatoid arthritis. QJ Med 1972;41:115-25. 